\title{
Reservoir yield intercomparison of large dams in Jaguaribe Basin-CE in climate change scenarios
}

\section{Intercomparação das vazões regularizadas de grandes reservatórios da bacia do Rio Jaguaribe-CE em cenários de mudanças climáticas}

\author{
Renato de Oliveira Fernandes ${ }^{1,2}$, Cleiton da Silva Silveira ${ }^{3}$, Ticiana Marinho de Carvalho Studart ${ }^{1}$ and \\ Francisco de Assis de Souza Filho ${ }^{1}$ \\ ${ }^{1}$ Universidade Federal do Ceará, Fortaleza, CE, Brazil \\ ${ }^{2}$ Universidade Regional do Cariri, Juazeiro do Norte, CE, Brazil \\ ${ }^{3}$ Universidade da Integração Internacional da Lusofonia Afro-Brasileira, Redenção, CE, Brazil \\ E-mails: renatodeof@gmail.com.br (ROF), cleitonsilveira@unilab.edu.br (CSS), ticianastudart2010@gmail.com (TMCS), \\ assissouzafilho@gmail.com (FASF)
}

\begin{abstract}
Climate changes can have different impacts on water resources. Strategies to adapt to climate changes depend on impact studies. In this context, this study aimed to estimate the impact that changes in precipitation, projected by Global Circulation Models (GCMs) in the fifth report by the Intergovernmental Panel on Climate Change (IPCC-AR5) may cause on reservoir yield ( $\left.\mathrm{Q}_{90}\right)$ of large reservoirs (Castanhão and Banabuiú), located in the Jaguaribe River Basin, Ceará. The rainfall data are from 20 GCMs using two greenhouse gas scenarios (RCP4.5 and RCP8.5). The precipitation projections were used as input data for the rainfall-runoff model (SMAP) and, after the reservoirs' inflow generation, the reservoir yields were simulated in the AcquaNet model, for the time periods of 2040-2069 and 2070-2099. The results were analyzed and presented a great divergence, in sign (increase or decrease) and in the magnitude of change of $\mathrm{Q}_{90}$. However, most Q90 projections indicated reduction in both reservoirs, for the two periods, especially at the end of the 21 th century.
\end{abstract}

Keywords: CMIP5; Reservoir yield; Coupling models.

\section{RESUMO}

As mudanças climáticas devem causar diversos impactos nos recursos hídricos. As estratégias de adaptação às alterações previstas no clima dependem de estudos de impactos. Nesse contexto, esse trabalho tem como objetivo estimar os impactos que as alterações na precipitação, projetada pelos Modelos de Circulação Global (MCGs) do quinto relatório do Painel Intergovernamental de Mudanças Climáticas (IPCC-AR5), podem causar nas vazões regularizadas $\left(\mathrm{Q}_{90}\right)$ de dois grandes reservatórios (Castanhão e Banabuiú) localizados bacia do Rio Jaguaribe, Ceará. Os dados de precipitação são provenientes de 20 MCGs em dois cenários de emissão de gases de efeito estufa (RCP4.5 e RCP8.5). As projeções de precipitação alimentaram um modelo chuva-vazão (SMAP) e posteriormente, após a geração das séries de vazões afluentes aos reservatórios, foram simuladas as vazões regularizadas pelos reservatórios no modelo AcquaNet para os períodos de 2040-2069 e 2070-2099. Os resultados foram comparados entre si e indicaram grandes divergências tanto quanto ao sinal (acréscimo ou redução) como quanto à magnitude da mudança na vazão regularizada. Entretanto, a maioria das projeções indica redução da $\mathrm{Q}_{90}$ nos reservatórios para os dois períodos, principalmente para o final do século.

Palavras-chave: CMIP5; Vazão regularizada; Acoplamento de modelos. 


\section{INTRODUCTION}

Climate changes can have impacts on various fields. In water resources, changes should occur in patterns of extreme events, in river flows, in evaporation rates and, consequently, in reservoir yields (IPCC, 2014).

Semiarid regions, such as Brazilian Northeast, where problems are caused by relatively scarce water, are considered the most vulnerable to the impacts of climate changes (MARENGO, 2009). In these regions, the presence of surface reservoirs is an essential condition to obtain water supplies (CAMPOS et al., 2003).

The most precise estimate of reservoir natural inflows and their yields provides various benefits; the main is planning water allocations, especially in a period of water rationing or scarcity. In Brazil, the determination of the amount of water to be allocated per user depends on grants (ANA, 2013). Grants are based on a reference yield (generally $\mathrm{Q}_{90}$ ) which assumes statistical stationarity of the hydrological series (MILLY et al., 2008).

In climate change scenarios, the reservoir inflows and their capacity for regulation will probably undergo great changes and may render the assumption of stationarity invalid. (BRAVO et al., 2013; MONTENEGRO; RAGAB, 2012; VAN VLIET et al., 2013; LÓPEZ-MORENO et al., 2014). Changes in hydrological processes and in water resources systems are consequences of the changes projected for climate variables such as precipitation and temperature. The first variable is directly associated with basin runoff, while the second is related to the evaporation rates in the reservoirs.

In order to deal with the projected impacts of climate changes on water resources, the management system must adopt strategies for adaptation (OLMSTEAD, 2014). The measures to adapt the water resources system to climate change impacts usually combine investments in infrastructure (hard strategies) and changes of policies and economic incentives, changes in cultural patterns or patterns of production and consumption (soft strategies) (BATES et al., 2008; GLEICK, 2003).

The Brazilian Panel on Climate Changes (PBMC - Painel Brasileiro de Mudanças Climáticas) (PBMC, 2014) makes several recommendations for the use of measures to adapt the water resources system to the projected changes. The purpose of adopting these measures is to increase the response capacity and reduce the vulnerability of populations and ecosystems.

Independent of adaptive measures to be adopted, there is a need to anticipate possibilities to define actions. Studies of climate processes needed to anticipate the management actions in water resources, are generally based on the results of Global Climate Models (GCMs). The GCMs simulate the planet's current climate, known as the baseline scenario and project future changes based on greenhouse gas emission scenarios which are related to social, economic and technological development, besides population growth, political actions, etc.

In this study, the impacts of recent climate change scenarios of the Intergovernmental Panel on Climate Changes- IPCC (IPCC, 2014) on the yields of large reservoirs in Ceará for future periods are evaluated. Two reservoirs located in the Jaguaribe River Basin - Castanhão and Banabuiú - were chosen. These two, which operate in parallel, are the most downstream reservoirs located in the basin and are responsible for the perenialization of the Jaguaribe and Banabuiú valleys.

\section{Climate change scenarios and uncertainties}

Climate change scenarios are usually generated based on Global Climate Models (GCMs) and their spatial resolution may be adjusted using the downscaling technique to provide an input to the impact studies (WILBY; WIGLEY, 1997; PIELKE Sr; WILBY, 2012). In water resources, the hydrological models generally use the results of the GCMs or of the Regional Circulation Models (RCM) as input data.

The outputs of the hydrological models, in turn, are used for studies on reservoir operation, crop irrigation, flood and drought forecasts, and other purposes (e.g. ADAM et al., 2015; CHIEN; YEH; KNOUFT, 2013; WATTS et al., 2011).

The GCMs simulate climate behavior worldwide based on specific initial and boundary conditions that represent possible futures in the atmospheric composition (MOSS et al., 2008). Often the bias of the GCMs is corrected using different techniques (EHRET et al., 2012). Currently the GCMs most used for studies of climate change impacts are those that appear in the IPCC reports.

The Coupled Model Intercomparison Project Phase 5 CMIP5 models (TAYLOR; STOUFFER; MEEHL, 2012) are examples of recent models that made up the the fifth report of IPCC (IPCC, 2013). The Greenhouse Gas (GHG) concentrations used as input data in the GCMs of the CMIP5 are represented in the so called Representative Concentration Pathways (RCPs) (VAN VUUREN et al., 2011). The GCMs create projections of different climate variables, such as precipitation and temperature (Figure 1), based on the RCPs.

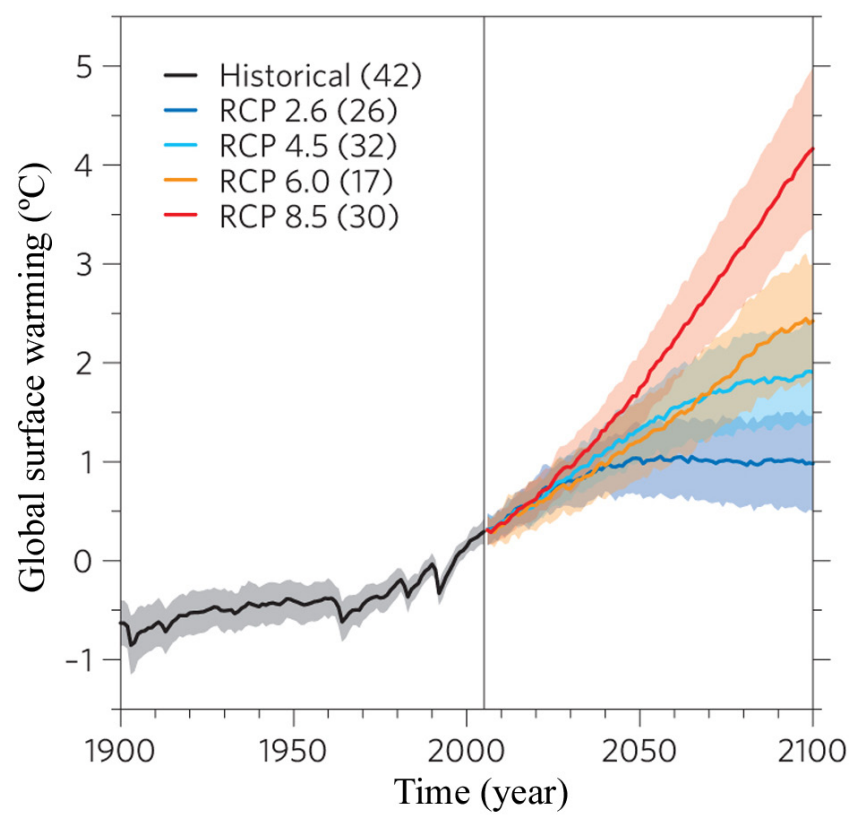

Figure 1. Global temperature increase used in IPCC-AR5 presented by the RCPs. The values in parentheses represent the number of GCMs. Source: Knutti and Sedlácek (2013). 
The RCPs contain representations of scenarios of more intense (RCP8.5), moderate (RCP6 and RCP4.5) and low (RCP2.6) GHG emissions. The RCPs are numbered according to the possible values that radioactive forcings (W. $\mathrm{m}^{-2}$ ) may take on in 2100 compared to the pre-industrial period.

The CMIP5 models show great advances over those of CMIP3, whose results were used to make up the IPCCs fourth report (AR4) on climate changes (MEEHL et al., 2007). The advances in CMIP5 include mainly a great number of models, more complex models and with high resolution, a better representation of the external forcings and other kinds of scenarios, including, explicitly, the GHG emission mitigation policies (TAYLOR; STOUFFER; MEEHL, 2012; SILLMANN et al., 2013).

Despite recent advances obtained using CMIP5 compared to CMIP3, Knutti and Sedlácek (2013) remark that the results obtained by the GCMs of CMIP5, extraordinarily do not present significant changes in the projections of temperature and precipitation considering the different scenarios on the global scale and compared to the GCMs of CMIP3.

For South America, Torres and Marengo (2013, 2014) evaluated the uncertainties in the projections of temperature and precipitation and the hotspots generated by the different GCMs present in CMIP3 and CMIP5 for the future climate, especially for the period of 2071-2100 compared to the 1961-1990 period (baseline). Forty-eight GCMs and scenarios SRES B1, A1B and A2 (CMIP3) and RCP 2.6, 4.5, 6.0 and 8.5 (CMIP5) were used. The methods used to evaluate the uncertainties were: REA - Reliability Ensemble Averaging, modified REA and Bayesian inference (GIORGI; MEARNS, 2002; TEBALDI et al., 2005). The simulations of the current climate (1961-1990), both with the CMIP3 and CMIP5 models, were a good representation of the basic climate aspects. However, the simulations coming from CMIP5 remained closer to the historical climate observed. As to future projections, the temperature increase proved greater than the interval of associated uncertainty for all of South America in the different periods, scenarios and ensembles of models, indicating high reliability of the projections. In the more intense radioactive forcings (A2 and RCP8.5) the probability that the temperature would exceed $2{ }^{\circ} \mathrm{C}$ in the $2071-2100$ period was greater than 90\% for all of South America. On the other hand, the methods for the evaluation of the uncertainty of precipitation were not different from the arithmetic average of the GCMs. The intervals of uncertainties of precipitation presented magnitudes that were equal to or greater than the changes projected by the models of CMIP3 and CMIP5, thus indicating low reliability of the GCM responses to represent future precipitation.

Silveira (2014), aiming to elaborate a planning system with multiple time and space scales, evaluated the tendency for change in precipitation and flow for the $21^{\text {st }}$ century from the data supplied by the GCMs of CMIP5, in scenarios RCP4.5 and RCP8.5, for catchments of the Brazilian electricity sector and those of the Jaguaribe-Metropolitano system in the state of Ceará. The hydrological model used was SMAP (LOPES; BRAGA JUNIOR; CONEJO, 1981) with the bias of monthly precipitation corrected by a probability distribution function. Although the CMIP 5 models are good representations of the seasonal precipitation patterns, with a high correlation with the historical values observed, there are divergences among the models regarding the future of rains in the different regions of the electricity sector.

Regarding the flows in the electricity sector, scenario RCP4.5 does not present a significant tendency in most of the catchments evaluated. On the other hand in RCP8.5 (a scenario with high GHG emissions), they show a tendency to changes in several basins, especially in the North region of Brazil, indicating the possibility of significant climate changes. In RCP8.5 and in the North sector, most of the models signal a negative tendency indicating the reduction of mean annual flows, especially at Belo Monte, In the Northeast sector for scenarios RCP4.5 and RCP8.5, the models presented differences in the catchment of the hydropower plant of Xingó, located on São Francisco River, showing great uncertainties in this basin for the $21^{\text {st }}$ century.

The tendencies to changes in the mean annual flows in the basins of the Jaguaribe-Metropolitano system in the state of Ceará (basins of the Orós, Castanhão, Banabuiú, Pacoti-Riachão) for the $21^{\text {st }}$ century, compared to the 1950-1999 period, presented great differences for scenarios RCP4.5 (10 GCMs) and RCP8.5 (14 GCMs). Despite the discrepancies, most of the models indicate a reduction of the mean annual flows in all the basins for the 21st century (SILVEIRA et al., 2014).

In the Castanhão reservoir basin for scenario RCP4.5, except for two GCMs, the results show that the flows must be reduced by at least $20 \%$ in all periods. On the other hand, in the RCP8.5 scenario, most of the GCMs also indicate a reduction in the mean flows. The reduction of flows in the two GHG scenarios analyzed is sometimes greater than $50 \%$ and close to $100 \%$ in the 2040-2069 and 2070-2099 periods for some GCMs. Nevertheless, two GCMs (IPSL-CM5A-LR and IPSL-CM5A-MR) presented an increase of up to $200 \%$ in the mean inflows of the two scenarios for the $21^{\text {st }}$ century.

In the Banabuiú reservoir basin most of the models also indicated a reduction of flows in both scenarios. For the period of 2010-2039, in scenarios RCP4.5 and RCP8.5, the reduction must be at least $10 \%$ and $5 \%$, respectively. In scenario RCP 8.5 the reduction ranged between $5 \%$ and $65 \%$ (2010-2039), 5\% and $75 \%(2040-2069)$ and $5 \%$ and $90 \%$ (2070-2098). The GCMs "IPSL-CM5A-LR" and "IPSL-CM5A-MR", as in the Castanhão basin, also signaled a large increase in the mean flows in the two scenarios for the 21 st century in the Banabuiú basin.

The recent results obtained by Knutti and Sedlácek (2013) on a global scale, Torres and Marengo $(2013,2014)$ for South America, and Silveira (2014) for the catchments of the electric sector and Ceará, show that the uncertainties involved in climate and hydrological projection are still high. From the physical standpoint, the uncertainties are associated mainly with the natural variability of the climate system, the trajectories or paths that can be followed by GHG emissions and aerosols, besides the response of the global climate system to the different concentrations of GHG. As to the modeling process, the uncertainties are related to the structure of the models (be they climatic or hydrological), the downscaling technique used (dynamic or statistical), spatial scale (global, regional or catchment), and temporal (years, decades or century), among others (KNUT'TI; SEDLÁCEK, 2013; PIELKE Sr; WILBY, 2012). 
Even with the advances in the GCMs from CMIP3 to CMIP5 in the concept of the GHG scenarios and increase of spatial resolution, the uncertainties are still one of the greatest challenges for impact studies, notably in water resources. The use of multiple models (such as those of CMIP3 and CMIP5) is an alternative to understand the uncertainties and become acquainted with the sign of projected change (addition or reduction), by most of the climate models (KNUT'TI, 2010).

Quality in the projection of flow by a hydrological model depends on the quality of the responses of the atmospheric models in forecasting the climate variables, especially precipitation. Acknowledging that the responses of the atmospheric model influence flow simulation on a catchment scale, many studies evaluate the predictive capacity of different GCMs and MCRs from the perspective of hydrological modeling (e.g., MARKSTROM et al., 2012; DANKERS et al., 2013; SCHEWE et al., 2013).

Any decision-making in water resources to adapt to the context of climate changes must consider the uncertainties involved (SIGEL et al., 2010). These uncertainties may possibly be minimized by increasing the spatial and temporal resolution of the climate models and the use of high performance computers (SHUKLA et al., 2009). However, the management system will still have to deal with the unpredictability resulting from the interaction of social and ecological systems (WAGENER et al., 2010).

\section{MATERIAL AND METHODS}

\section{Case study: Jaguaribe River-CE}

Jaguaribe River lies in the state of Ceará, Brazil. It is $633 \mathrm{~km}$ long, with a catchment of $74,000 \mathrm{~km}^{2}$, draining 81 municipalities, the equivalent of about $50 \%$ of the state territory. The catchment is formed by five sub-basins, the upper, middle and lower Jaguaribe River, Salgado River and Banabuiú River (Figure 2).

Jaguaribe is a highly regulated river basin. The three largest reservoirs in the State were constructed there, in terms of storage capacity $(\mathrm{K})$ and reservoir yield $\left(\mathrm{Q}_{90}\right)$ : Castanhão $\left(\mathrm{K}=6.7\right.$ billion $\mathrm{m}^{3}$ and $Q_{90}=29.0 \mathrm{~m}^{3} / \mathrm{s}$ ), Orós $\left(K=1.9\right.$ billion $\mathrm{m}^{3}$ and $Q_{90}=20.4 \mathrm{~m}^{3} / \mathrm{s}$ ) and Banabuiú ( $\mathrm{K}=1.6$ billion $\mathrm{m}^{3}$ and $\left.\mathrm{Q}_{90}=12.9 \mathrm{~m}^{3} / \mathrm{s}\right)(\mathrm{SRH}$, 2011a, b, c). It is estimated that there are another 4,713 smaller reservoirs in this basin (FORMIGA-JOHNSSON; KEMPER, 2005). The main water users are the irrigators, fish farmers, and water utilities. There is an aggregate demand of the industrial complex in the metropolitan area of Fortaleza, agribusiness and agricultural systems in 'Canal do Trabalhador' (PINHEIRO et al., 2007; MARTINS et al., 2013).

The allocation of the reservoir yields is decided at the end of the first semester (usually in June) in so-called "negotiated allocation meetings" and "planning seminars" (AQUINO et al., 2013; SILVA; OLIVEIRA; BEZERRA, 1996). At these meetings and seminars, simulations of reservoir emptying are performed considering the stock of water, the demands from the previous years, and the absence of water inputs in the second semester (dry season). The long term water allocation is determined by grants.

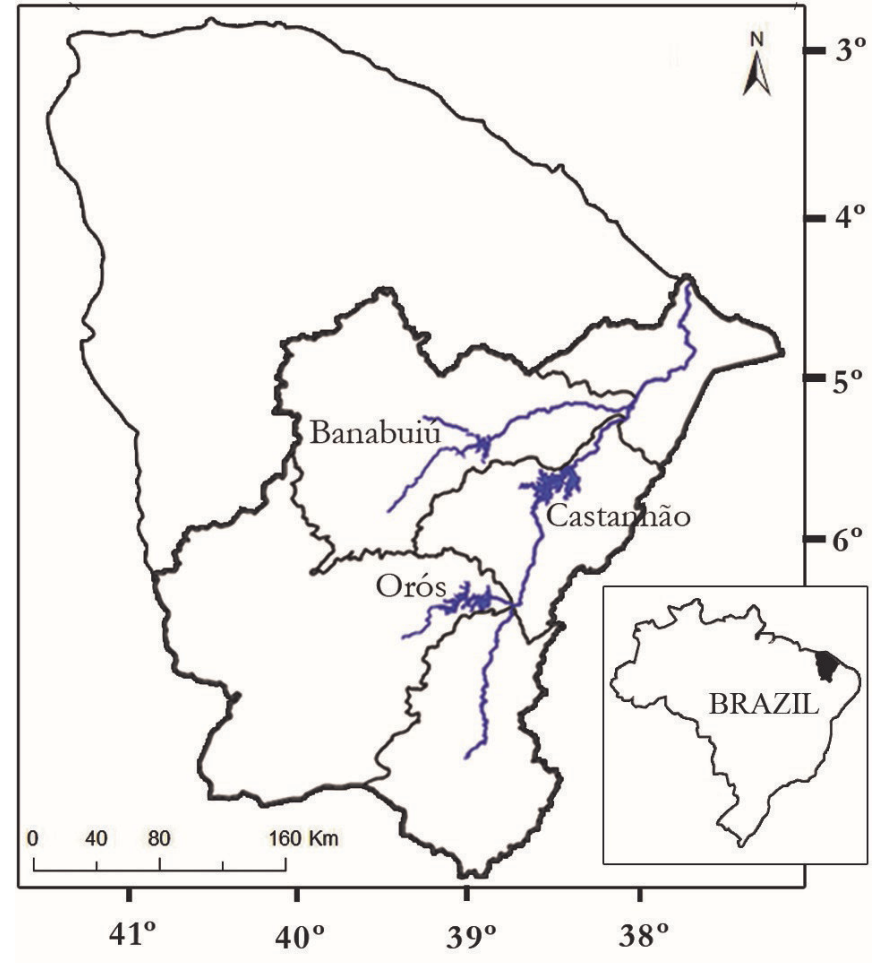

Figure 2. Location of the study area and spatial distribution of Castanhão, Orós and Banabuiú reservoirs in Ceará State map.

\section{Castanhão and Banabuiú reservoir yields in climate change scenarios}

This study uses a top-down type approach (WILBY; DESSAI, 2010) involving the extraction of rainfall projects from 20 GCMs using the statistical downscaling technique (WILBY; WIGLEY, 1997). The rainfall scenarios of the GCMs were used as input data in a rainfall-runoff model to estimate the inflows. Later the scenarios of inflows fed a reservoir model to simulate the reservoir yields of Castanhão and Banabuiú reservoirs, in two distinct future periods (Figure 3). Although it is acknowledged that the flows released from Orós reservoir have an impact on the reservoir yields of Castanhão, the first reservoir mentioned was not included in this study because these impacts are considered mainly associated with the definition of operational rules that determine the flow to be released downstream from this reservoir.

The scenarios of inflows to Castanhão and Banabuiú reservoirs are the amplified results of Silveira et al. (2014), which determined the natural inflows into the four main reservoirs of the Jaguaribe-Metropolitano system, including Castanhão and Banabuiú, for the $21^{\text {st }}$ century, based on 10 GCMs for RCP4.5 and 14 GCMs for the RCP8.5 of CMIP5. This study expands the number of GCMs to 20 (Table 1) in RCP4.5 and RCP8.5. The RCPs, which are input data to the GCMs involve a large number of variables, such as adoption of technologies, land use, $\mathrm{CO}_{2}$ emission, etc. (VAN VUUREN et al., 2011; MEINSHAUSEN et al., 2011). The radioactive forcings of the RCP4.5 and RCP8.5 take on the value of $4.5 \mathrm{~W} / \mathrm{m}^{2}$ and $8.5 \mathrm{~W} \cdot \mathrm{m}^{-2}$ in the year of 2100 , respectively. 
The estimate of changes in the reservoir inflows and yields were obtained by calculating the deviations from the projections involving the baseline scenario (Equations 1 and 2). The baseline scenario which is necessary to compare the changes in the hydrological regime and also to reduce systematic errors of the models, refers to the period from 1961 to 1990.

$$
\delta_{a f l u .}=\left(\frac{Q_{a f l u . p r o j}-Q_{a f l u . ~ b a s e}}{Q_{a f l u . ~ b a s e}}\right) \times 100
$$

$$
\delta_{90 \%}=\left(\frac{Q_{90 \% \text { proj }}-Q_{90 \% \text { base }}}{Q_{90 \% \text { base }}}\right) \times 100
$$

Where:

$\delta_{a f .}$ and $\delta_{90 \%}$ - represent the variation of the mean inflows and $\mathrm{Q}_{90}$ in the reservoirs, respectively, in relation to the baseline scenario (\%). $\mathrm{Q}_{\text {aflu. proj. }}$ and $\mathrm{Q}_{90 \% \text {. proj }}$ - represent the mean inflows and yields projected for the future based on the rainfall data of each GCM, respectively $\left(\mathrm{m}^{3} / \mathrm{s}\right)$.

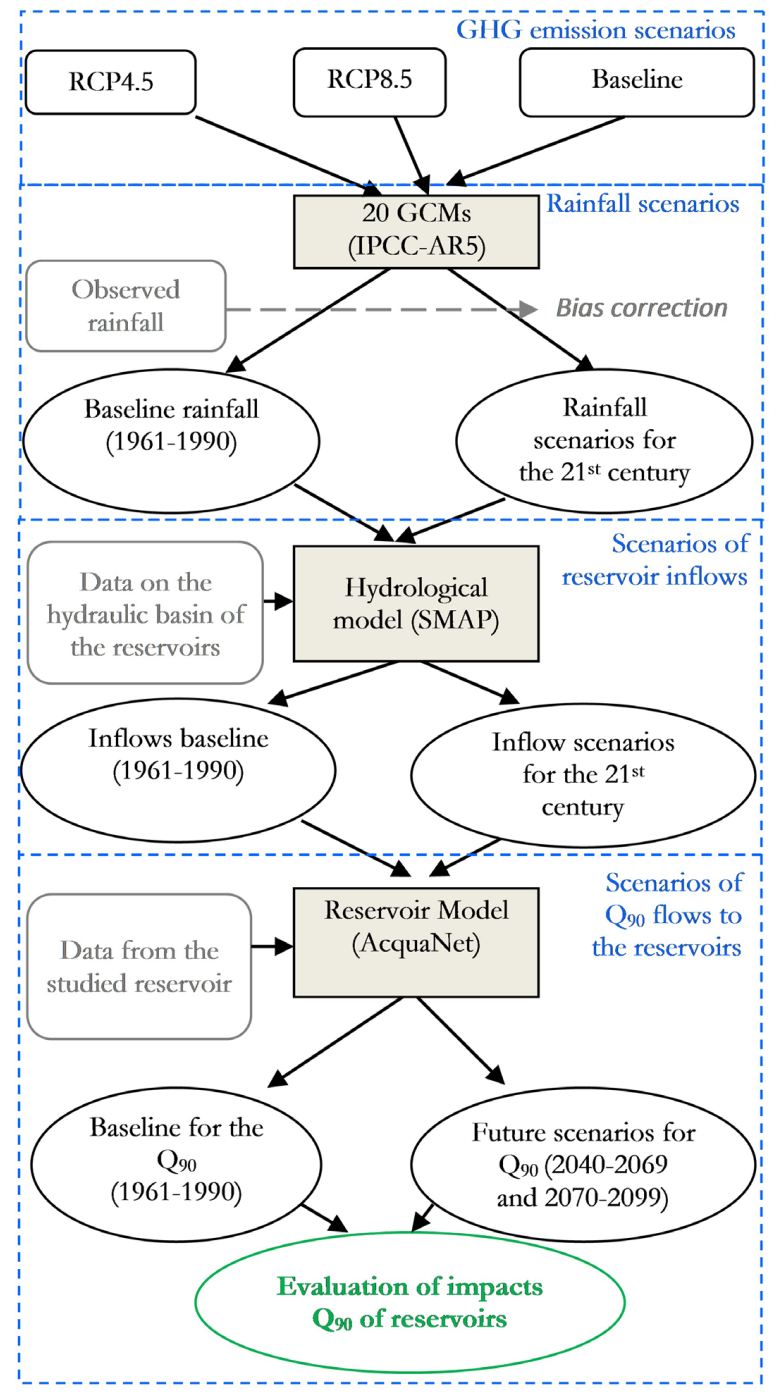

Figure 3. Representation of the methodology adopted to evaluate the impact of climate changes in $\mathrm{Q}_{90}$.
$\mathrm{Q}_{\text {aflu, base. }}$ and $\mathrm{Q}_{90 \% \text { base }}$ - represent the inflows and yields in the baseline scenario obtained from the rainfall data of the GCMs, respectively $\left(\mathrm{m}^{3} / \mathrm{s}\right)$.

The hydrological model, of the rainfall-runoff type was the Soil Moisture Accounting Procedure - SMAP, which is conceptual and deterministic, with a concentrated structure This model is part of the large family of hydrological models for the calculation of soil humidity. Its structure is relatively simple and its parameters are related to the mean physical parameters in the basin.

The water balance in the reservoirs took into account only the mean inflows projected by the hydrological model on the monthly scale. Therefore, the losses due to future evaporation influenced mainly by the increase in temperature were ignored. The evaporation data and the physical characteristics are the values presented in the environmental inventory for the two reservoirs being studied (SRH, 2011a, c).

The model used to simulate the reservoirs was AcquaNet (PORTO; MÉLLO JUNIOR; ROBERTO, 2005). This model represents the water resources system through nodes, and these are volume nodes (reservoirs) and passage nodes (confluences, points of diversion, points of entry, and points of demand) and arcs or links (canals, supply pipes, and natural river reaches).

Figure 4 presents the flow network elaborated in the AcquaNet model and used to simulate the yields of the two reservoirs that are being studied. The elements "Qreg_banab" and "Qreg_cast" represent the water demand in the Banabuiú and Castanhão reservoirs respectively. Links L1 and L2 represent reaches of the Banabuiú river, while L3, L4 and L5 represent the Jaguaribe river (without a scale). The drain at the end of the network is an abstraction used in the model to represent the water that exceeds the demands that have greater priorities.

In AcquaNet it is possible to define a set of priorities for the demands and for water storage in the reservoirs. The priorities vary from 1 to 99, and the lowest values have the highest priority. The "Qreg_banab" and "Qreg_cast" demands were simulated with high priorities (priority equal to 1), and the drain with a low priority (priority equal to 99). The reservoirs had priorities equal to 50 . The simulations in the reservoirs were performed for yields with $90 \%$ guarantee $\left(\mathrm{Q}_{90}\right)$, i.e., a frequency of $10 \%$ of non-provision of total demand.

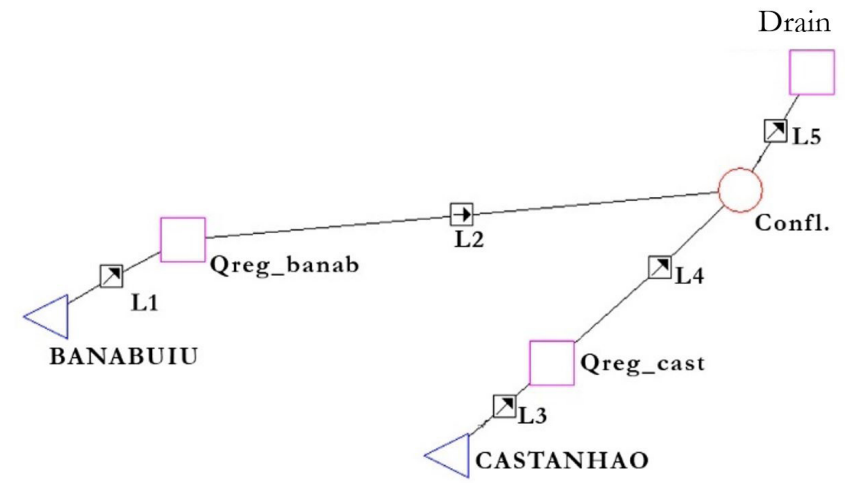

Figure 4. Flow network used to simulate the reservoir yields of Castanhão and Banabuiú reservoirs in the AcquaNet model. 
Table 1. GGMs of the CMIP5 used.

\begin{tabular}{cl}
\hline GCM & \multicolumn{1}{c}{ Modeling Center } \\
\hline ACCESS1-0 & $\begin{array}{l}\text { CSIRO (Commonwealth Scientific and Industrial Research Organisation, Australia), and BOM (Bureau of } \\
\text { Meteorology, Australia) }\end{array}$ \\
\hline ACCESS1-3 & Beijing Climate Center, China Meteorological Administration \\
\hline BCC-CSM1-1 & Canadian Centre for Climate Modelling and Analysis \\
\hline CCSM4 & National Center for Atmospheric Research \\
\hline CESM1-BGC & National Science Foundation, Department of Energy, National Center for Atmospheric Research \\
\hline CESM1-CAM5 & Centro Euro-Mediterraneo per I Cambiamenti Climatici \\
\hline CMCC-CM & Geophysical Fluid Dynamics Laboratory \\
\hline GFCC-CMS & $\begin{array}{l}\text { Met Office Hadley Centre (additional HadGEM2-ES realizations contributed by Instituto Nacional de Pesquisas } \\
\text { Espaciais) }\end{array}$ \\
\hline GFDL-ESM2M & Institute for Numerical Mathematics \\
\hline HadGEM2-AO & Institut Pierre-Simon Laplace \\
\hline HadGEM2-ES & $\begin{array}{l}\text { Atmosphere and Ocean Research Institute (The University of Tokyo), National Institute for Environmental Studies, } \\
\text { and Japan Agency for Marine-Earth Science and Technology }\end{array}$ \\
\hline IPSL-CM4 & $\begin{array}{l}\text { Japan Agency for Marine-Earth Science and Technology, Atmosphere and Ocean Research Institute (The University } \\
\text { of Tokyo), and National Institute for Environmental Studies }\end{array}$ \\
\hline IPSL-CM5B-LR & Max Planck Institute for Meteorology (MPI-M) \\
\hline MIROC5 &
\end{tabular}

\section{RESULTS AND DISCUSSION}

\section{Projections of the reservoir inflows}

The variation of the mean inflows $\left(\delta_{a f l u}\right)$ obtained from the rainfall-runoff model considering the precipitation data of 20 GCMs of CMIP5 presented divergences (Figure 5). There was less divergence in the inflows $\left(\delta_{a f u}\right)$ for the $2040-2069$ period than for the 2070-2099 period in both GHG emission scenarios. Hence, for inflows into the two reservoirs, the results are less divergent in the first period (2040-2069) than in the second (2070-2099). The divergences are associated with the representation of the climate processes present in the structure of each model and corroborated the divergences in the results of the GCMs found by Torres and Marengo (2013, 2014), for precipitations in South America, and Silveira (2014) for the inflows in different basins of the electricity sector and of Ceará.

Analysis of the variation of mean inflows $\left(\delta_{a f u}\right)$ for each reservoir shows that the change in the Castanhão presents a negative tendency in both periods, as can be found in most of the projections $(65 \%)$ that point to negative values and consequently median values lower than zero. On the other hand, in Banabuiú, the tendency, according to the median was positive or null. These results agree with Silveira et al. (2014) as to the tendency for the reduction of inflows signaled by most of the GCMs in Castanhão. However, the addition of up to $200 \%$ in the inflows detected by the authors cited for GCM "IPSL-CM5A-LR", in this study, did not surpass $63 \%$. The projections of the inflows associated with "GFDL-CM3" were those that presented the greatest additions, and could reach $71 \%$ for Banabuiú and $108 \%$ for Castanhão during the 2040-2069 period and RCP8.5.

In general, the diversions of the inflows $\left(\delta_{\text {affu. }}\right)$ increase with the change of the GHG emission scenario from moderate
(RCP4.5) to more intense (RCP8.5) and from the mid-21 ${ }^{\text {st }}$ century (2040-2069) to the end of this century (2070-2099).

\section{Projections of reservoir yields}

The changes in the inflows $\left(\delta_{a f u l}\right)$ to the Castanhão and Banabuiú reservoirs were reflected in the values of flow diversions $\mathrm{Q}_{90}\left(\delta_{90 \%}\right)$. Figure 6 shows the changes in reservoir yields with a $90 \%$ guarantee $\left(\delta_{90 \%}\right)$ in the two reservoirs studied, considering the rainfall data of the $20 \mathrm{GCMs}$ in the RCP4.5 and RCP8.5 scenarios for the 2040-2069 and 2070-2099 periods that were used as input data in the hydrological model. The percentages shown in Figure 6 represent a reduction (bars on the negative axis) or increase (bars on the positive axis), per period and GHG emission scenario.

The diversions of the reservoir yields $\left(\delta_{90^{\circ}}\right)$ are very different from each other, both as to the sign (reduction or addition), and as to the magnitude of change. Figure 6 shows that the projections from some models indicate a reduction greater than $60 \%$, in the two reservoirs simultaneously: MPI-ESM-MR, during the 2070-2099 period for RCP4.5 (Figure 6C), CESM1-BGC, during the 2040-2069 period for RCP8.5 (Figure 6B) and BCC-CSM1-1, during the 2070-2099 period and RCP8.5 (Figure 6D). "MIROC-ESM-CHEM" also pointed at a reduction greater than $60 \%$, but only for Banabuiú in the 2070-2099 period and RCP4.5. The reductions in $\mathrm{Q}_{90}$ greater than $60 \%$ originating in the data of the GCMs "CESM1-BGC" and "BCC-CSM1-1" in RCP8.5 agree with the results obtained by Silveira et al. (2014) who identified these GCMs as those that project large reductions in the inflows to the two reservoirs and that consequently affect the yields.

The great reductions in $\mathrm{Q}_{90}$ presented in the GCMs mentioned, show that even though the 20 GCMs were fed the same information, they may have different responses, mainly due 


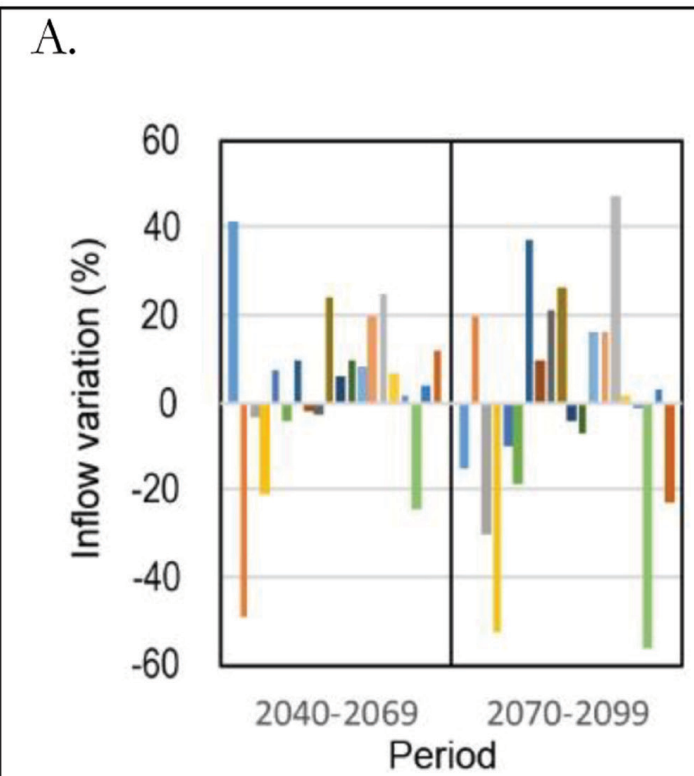

B.

C.

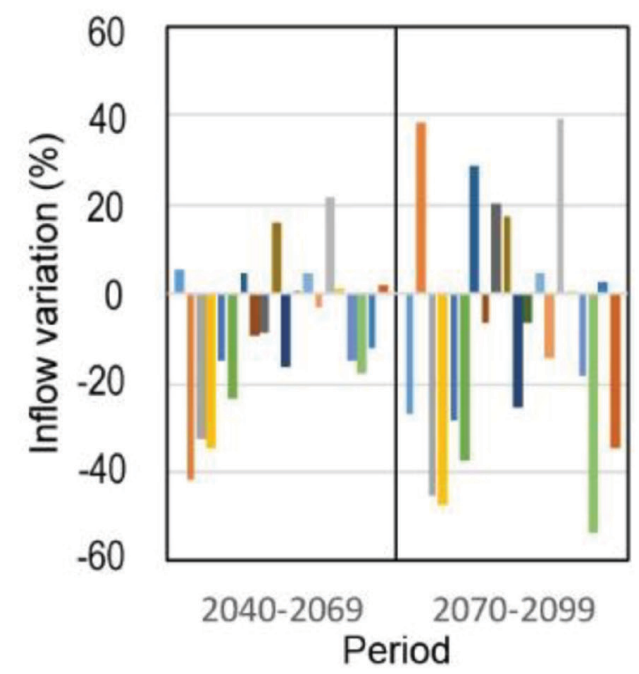

D.
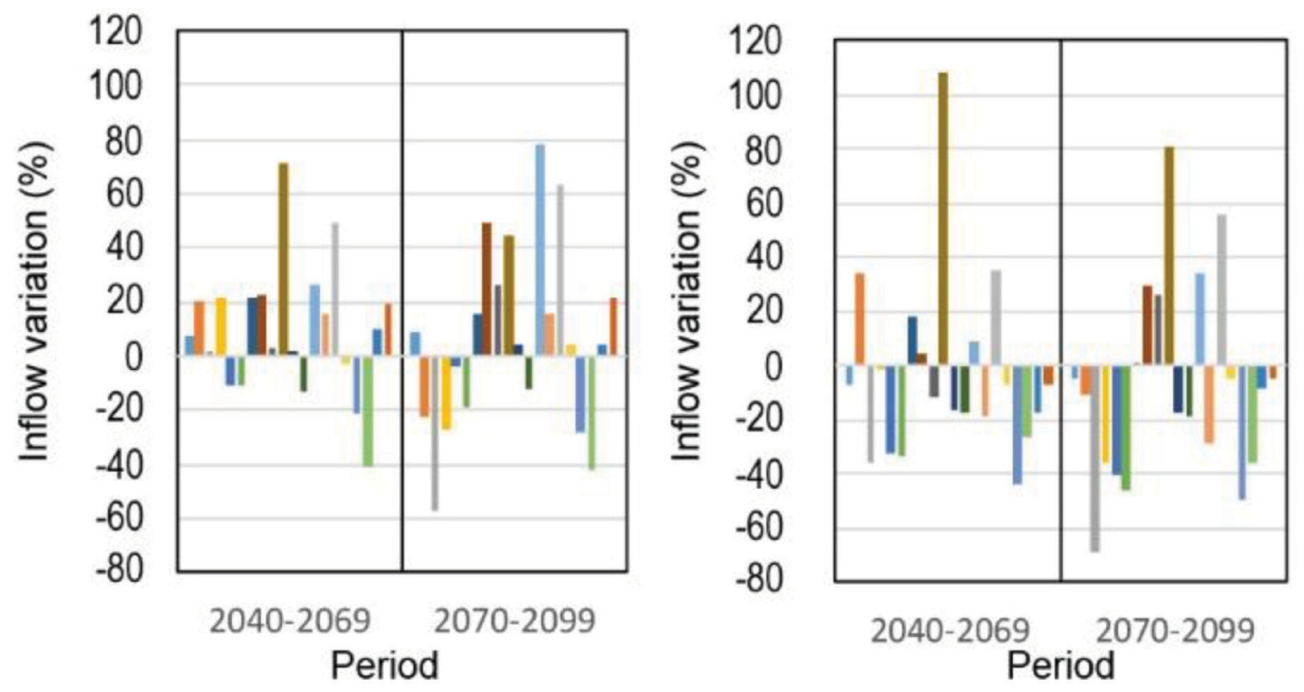

\begin{tabular}{|llll|}
\hline$\square$ ACCESS1-0 & $\square$ ACCESS1-3 & BCC-CSM1-1 & CanESM2 \\
$\square$ CCSM4 & $\square$ CESM1-BGC & $\square$ CESM1-CAM5 & $\square$ CMCC-CM \\
$\square$ CMCC-CMS & $\square$ GFDL-CM3 & $\square$ GFDL-ESM2M & $\square$ HadGEM2-AO \\
$\square$ HadGEM2-ES & $\square$ INM-CM4 & $\square$ IPSL-CM5A-LR & $\square$ IPSL-CM5B-LR \\
$\square$ MIROC5 & $\square$ MIROC-ESM-CHEM & $\square$ MPI-ESM-LR & $\square$ MPI-ESM-MR \\
\hline
\end{tabular}

Figure 5. Variation of the mean inflow (Saflu.) in the Banabuiú (A, C) and Castanhão (B, D) reservoirs for the 2040-2069 and 2070-2099 periods, based on the rainfall data projected by 20 GCMs of CMIP5 for scenarios RCP4.5 (A, B) and RCP8.5 (C, D).

to the differences in the representation of the physical processes in the structure of each model.

In general, the diversions of $\mathrm{Q}_{90}\left(\delta_{90^{\circ}}\right)$ which indicated a reduction in both reservoirs and periods, presented higher percentages than those that signaled an increase, both for RCP4.5 and for RCP8.5.

Considering the changes projected in $\mathrm{Q}_{90}\left(\delta_{90 \%}\right)$ generated for the two reservoirs and scenarios ( 80 projections per reservoir),
11 signaled additions greater than $20 \%$. On the other hand, 41 projections indicated a reduction greater than $20 \%$. These reductions may occur mainly at the end of the century (2070-2099), given that most of the projections agree with the reduction.

The data from the CGMs that indicated an increase greater than 20\% were: GFDL-CM3, for Castanhão (in all scenarios and periods), and for Banabuiú (for 2040-2069 in RCP8.5): MIROC-ESMCHEM, for Castanhão (2040-2069, in RCP4.5, Figure 6A) and 
RCP8.5 (Figure 6B); CESM1-BGC, in the 2070-2099 period in RCP8.5 for Castanhão (Figure 6D); ACCESS1-0, in the 2040-2069 period in RCP8.5 for Banabuiú (Figure 6B), HadGEM2-AO and CCSM4, in the 2040-2069 period and RCP4.5 for Banabuiú (Figure 6A).

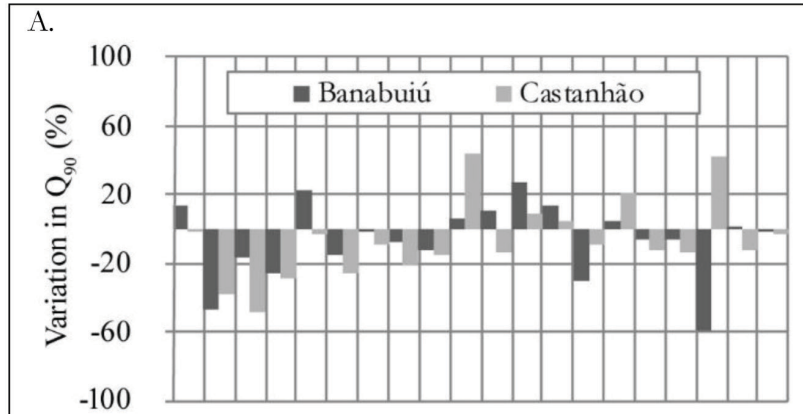

B.

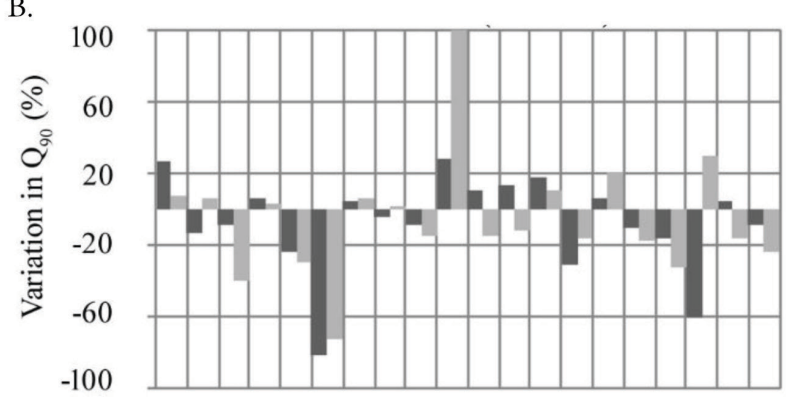

C.

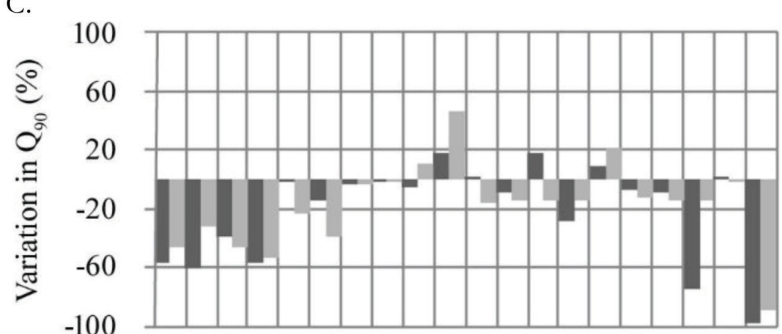

D.

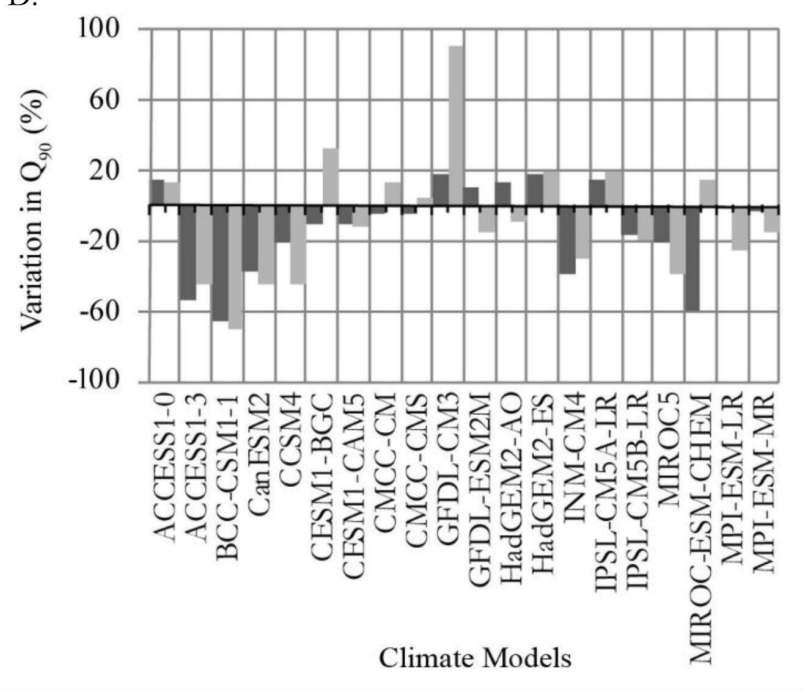

Figure 6. Variation in reservoir yields of Castanhão and Banabuiú, with a $90 \%$ guarantee for scenarios RCP4.5 (A, C) and RCP8.5 (B, D), 2040-2069 (A, B) and 2070-2099 (C, D) periods for 20 GCMs of CMIP5.
Particularly "GFDL-CM3" in RCP8.5, meant for Castanhão, an addition of $\mathrm{Q}_{90}$ much above the other 19 GCMs for the two periods. The latter result is associated with the increase signaled by "GFDL-CM3" for inflows to Castanhão of up to 108\% for 2040-2069 and 80\% for 2070-2099. Thus, the projections that meant greater changes in $\mathrm{Q}_{90}$ in reservoirs consistently correspond also to the inflow data with greater variations.

The variations in the flows with a $90 \%$ guarantee $\left(\delta_{90 \%}\right)$, for the periods analyzed indicate a tendency to the reduction of the water availability in the two reservoirs. Although the results present divergences, this information shows the interval of variation of $\mathrm{Q}_{90}$ and can make it easier to anticipate the adaptive measures of the region to the probable changes in the water availability due to climate changes, especially regarding the reduction of $\mathrm{Q}_{90}$ of Castanhão reservoir, which, for the projections with the greatest reductions, may compromise the supply of several user sectors in the state of Ceará, including the metropolitan area of Fortaleza and the Jaguaribe valley.

\section{CONCLUSION}

This study evaluated the possible impacts of changes in precipitation projected by the GCMs of IPCC-AR5 (CMIP5) on inflows and regulated by two large surface reservoirs (Castanhão and Banabuiú), located in the Jaguaribe river basin in Ceará.

The variation of inflows $\left(\delta_{\text {aful }}\right)$ and $\mathrm{Q}_{90}\left(\delta_{90 \%}\right)$, for the Castanhão and Banabuiú reservoirs, estimated from data of 20 GCMs of CMIP5, for the periods of 2040-2069 and 2070-2099, in the emission scenarios RCP4.5 (moderate) and RCP8.5 (intense), indicated great divergences among them, both as to the sign (addition or reduction), and as to the magnitude of change.

The divergences between the diversions in the inflows $\left(\delta_{a f u}\right)$ to Castanhão and Banabuiú increase with the change of the scenario from moderate GHG emission (RCP4.5) to more intense (RCP8.5) and from the mid-21 ${ }^{\text {st }}$ century (2040-2069) to the end of this century (2070-2099). Despite these divergences, it can be seen that the inflows projected for Castanhão tended to be reduced, while for Banabuiú the tendency is positive or null.

As to $\mathrm{Q}_{90}$, it can however be observed that most of the diversions $\left(\delta_{90 \%}\right)$ indicate a tendency for reduction in both reservoirs. This reduction may be greater than $60 \%$ in relation to the baseline scenario, as indicated in the changes generated from four GCMs. Moreover, in $51 \%$ of the projections, in $\mathrm{Q}_{90}$ they indicated a reduction greater than $20 \%$ and another $12.5 \%$ signaled an increase greater than $20 \%$ in $\mathrm{Q}_{90}$.

The results also indicated that if the changes in $\mathrm{Q}_{90}$ occur, there is a great chance that there will be a more intense reduction, given that the percentages of reduction (negative values) are, in absolute values, greater than the percentages projected for the increase of $\mathrm{Q}_{90}$ as related to the baseline period.

The reductions in the values of the reservoir yields can be even greater, if the simulations take into account the increased evaporation rates, influenced mainly by the increased temperature predicted for the future.

The international policies for mitigation discuss the possibility of minimizing the mean increase of global temperature to values between $1.5^{\circ} \mathrm{C}$ and $2{ }^{\circ} \mathrm{C}$, which is compatible with the 
RCP4.5 scenario and the 2070-2099 period, analyzed in the present study. Thus, there is a pressing need to define strategies to adapt the water resources sector to climate changes. Considering the uncertainties inherent to the process described, the adaptation strategies need to be flexible and dynamic, and should evolve over time, with new information and further knowledge.

\section{ACKNOWLEDGEMENTS}

The first author thanks the Ceará Foundation for Support to Scientific and Technological Development (FUNCAP - Fundação Cearense de Apoio ao Desenvolvimento Científico e Tecnológico) for financial support, through the $\mathrm{PhD}$ fellowship, and the Regional University of Cariri (URCA) for leave from teaching activities in order to perform this study.

\section{REFERENCES}

ADAM, K. N.; FAN, F. M.; BRAVO, J. M.; COLLISCHONN, W.; PONTES, P. R. M. Mudanças climáticas e vazões extremas na Bacia do Rio Paraná. Revista Brasileira de Recursos Hídricos, v. 20, n. 4, p. 999-1007, 2015. http://dx.doi.org/10.21168/rbrh. v20n4.p999-1007.

ANA - Agência Nacional de Águas. Manual de procedimentos técnicos e administrativos de outorga de direito de uso de recursos hidricos. Brasília: ANA, 2013. 249 p.

AQUINO, S. H. S.; SILVA, S. M. O.; SILVA, D. C.; SOUZA FILHO, F. A. Alocação de longo prazo no estado do Ceará. In: SOUZA FILHO, F. A.; CAMPOS, J. N. B.; AQUINO, S. H. S. (Orgs.). Gerenciamento de recursos hídricos no semiárido. Fortaleza: Edição Gráfica e Editora, 2013. p. 257-275.

BATES, B. C.; KUNDZEWICZ, Z. W.; WU, S.; PALUTIKOF, J. P. (Eds.). Climate change and water. Geneva: IPCC, 2008. 210 p. Intergovernmental Panel on Climate Change Technical Paper, 6.

BRAVO, J. M.; COLLISCHONN, W.; DA PAZ, A. R.; ALLASIA, D.; DOMECQ, F. Impact of projected climate change on hydrologic regime of the Upper Paraguay River basin. Climatic Change, v. 127, n. 1, p. 27-41, 2013. http://dx.doi.org/10.1007/s10584-013-0816-2.

CAMPOS, J. N. B.; STUDART, T. M. C.; MARTINZ, D. D. G.; NASCIMENTO, L. S. V. Contribuições ao debate sobre as eficiências de pequenos e grandes reservatórios. Revista Brasileira de Recursos Hidricos, v. 8, n. 2, p. 31-38, 2003. http://dx.doi.org/10.21168/ rbrh.v8n2.p31-38.

CHIEN, H.; YEH, P. J. F.; KNOUFT, J. H. Modeling the potential impacts of climate change on streamflow in agricultural watersheds of the Midwestern United States. Journal of Hydrology (Amsterdam), v. 491, p. 73-88, 2013. http://dx.doi.org/10.1016/j. jhydrol.2013.03.026.

DANKERS, R.; ARNELL, N. W.; CLARK, D. B.; FALLOON, P.; FEKETE, B. M.; GOSLING, S. N.; HEINKE, J.; KIM, H.;
MASAKI, Y.; SATOH, Y.; STACKE, T. First look at changes in flood hazard in the Inter-Sectoral Impact Model Intercomparison Project ensemble. Proceedings of the National Academy of Sciences of the United States of America, v. 111, n. 9, 3257-3261, 2013. http:// dx.doi.org/10.1073/pnas.1302078110. PMid:24344290.

EHRET, U.; ZEHE, E.; WULFMEYER, V.; WARRACH-SAGI, K.; LIEBERT, J. Should we apply bias correction to global and regional climate model data? Hydrology and Earth System Sciences Discussions, v. 9, n. 4, p. 5355-5387, 2012. http://dx.doi.org/10.5194/ hessd-9-5355-2012.

FORMIGA-JOHNSSON, R. M.; KEMPER, K. E. Institutional and policy analysis of river basin management in the Jaguaribe River Basin, Ceará, Brazil. Washington, DC: The World Bank, 2005. Policy Research Working Paper 3649.

GIORGI, F.; MEARNS, L. O. Calculation of average, uncertainty range, and reliability of regional climate changes from AOGCM simulations via the "Reliability Ensemble Averaging" (REA) method. Journal of Climate, v. 15, n. 10, p. 1141-1158, 2002. http://dx.doi. org/10.1175/1520-0442(2002)015<1141:COAURA>2.0.CO;2.

GLEICK, P. H. Global freshwater resources: soft-path solutions for the 21st century. Science, v. 302, n. 5650, p. 1524-1528, 2003. PMid:14645837. http://dx.doi.org/10.1126/science.1089967.

IPCC - Intergovernmental Panel on Climate Change. Climate change: the physical science basis. Cambridge: Cambridge University Press, 2013. 1535 p. Contribution of Working Group I to the Fifth Assessment Report of the Intergovernmental Panel on Climate Change.

IPCC - Intergovernmental Panel on Climate Change. Summary for policymakers. In: FIELD, C. B.; BARROS, V. R.; DOKKEN, D. J.; MACH, K. J.; MASTRANDREA, M. D.; BILIR, T. E.; CHATTERJEE, M.; EBI, K. L.; ESTRADA, Y. O.; GENOVA, R. C.; GIRMA, G.; KISSEL, E. S.; LEVY, A. N.; MACCRACKEN, S.; MASTRANDREA, P. R.; WHITE, L. L. (Eds.). Climate change: impacts, adaptation, and vulnerability: part A: global and sectoral aspects. Cambridge: Cambridge University Press, 2014. p. 1-32. Contribution of Working Group II to the Fifth Assessment Report of the Intergovernmental Panel on Climate Change.

KNUTTI, R. The end of model democracy? Climatic Change, v. 102, n. 3-4, p. 395-404, 2010. http://dx.doi.org/10.1007/s10584010-9800-2.

KNUTTI, R.; SEDLÁCEK, J. Robustness and uncertainties in the new CMIP5 climate model projections. Nature Climate Change, v. 3 , n. 4, p. 369-373, 2013. http://dx.doi.org/10.1038/nclimate1716.

LOPES, J. E. G.; BRAGA JUNIOR, B. P. F.; CONEJO, J. G. L. A. Simulação hidrológica: aplicações de um modelo simplificado. In: SIMPÓSIO BRASILEIRO DE RECURSOS HÍDRICOS, 3. 1981, Fortaleza. Fortaleza: [s.n.], 1981. p. 42-62. 
LÓPEZ-MORENO, J. I.; ZABALZA, J.; VICENTE-SERRANO, S. M.; REVUELTO, J.; GILABERTE, M.; AZORIN-MOLINA, C.; MORÁN-TEJEDA, E.; GARCÍA-RUIZ, J. M.; TAGUE, C. Impact of climate and land use change on water availability and reservoir management: Scenarios in the Upper Aragón River, Spanish Pyrenees. The Science of the Total Environment, v. 493, p. 1222-1231, 2014. PMid:24090497. http://dx.doi.org/10.1016/j. scitotenv.2013.09.031.

MARENGO, J. A. Vulnerabilidade, Impactos e adaptação as mudanças de clima no semiárido do Brasil. Parcerias Estrategicas, v. 1, n. 1, p. 149-176, 2009.

MARKSTROM, S. L.; HAY, L. E.; WARD-GARRISON, C. D.; RISLEY, J. C.; BATTAGLIN, W. A.; BJERKLIE, D. M.; CHASE, K. J.; CHRISTIANSEN, D. E.; DUDLEY, R. W.; HUNT, R. J.; KOCZOT, K. M.; MASTIN, M. C.; REGAN, R. S.; VIGER, R. J.; VINING, K. C.; WALKER, J. F. Integrated watershed-scale response to climate change for selected basins across the United States. Reston: U.S. Geological Survey, 2012. 143 p. Scientific Investigations Report, 2011-5077.

MARTINS, E. S. P. R.; BRAGA, C. F. C.; NYS, E.; SOUZA FILHO, F. A.; FREITAS, M. A. S. Impacto das mudanças climáticas e projeções de demanda sobre o processo de alocação de água em duas bacias do Nordeste Semiárido. Brasília: ANA, 2013. 88 p. Série Água Brasil 8, v. 1.

MEEHL, G. A.; COVEY, C.; DELWORTH, T.; MOJIB, L.; MCAVANEY, B.; MITCHELL, J. F. B.; STOUFFER, R. J.; TAYLOR, K. E. The WCRP CMIP3 multimodel dataset: a new era in climate change research. Bulletin of the American Meteorological Society, v. 88, n. 9, p. 1383-1394, 2007. http:/ /dx.doi.org/10.1175/ BAMS-88-9-1383.

MEINSHAUSEN, M.; SMITH, S. J.; CALVIN, K. V.; DANIEL, J. S.; KAINUMA, M. L. T.; LAMARQUE, J.-F.; MATSUMOTO, K.; MONTZKA, S. A.; RAPER, S. C. B.; RIAHI, K.; THOMSON, A. M.; VELDERS, G. J. M.; VAN VUUREN, D. The RCP greenhouse gas concentrations and their extension from 1765 to 2300. Climatic Change, 2011.

MILLY, P. C. D.; BETANCOURT, J.; FALKENMARK, M.; HIRSCH, R. M.; KUNDZEWICZ, Z. W.; LETTENMAIER, D. P.; STOUFFER, R. J. Stationarity is dead: whither water management? Science, v. 319, n. 5863, p. 573-574, 2008. PMid:18239110. http:// dx.doi.org/10.1126/science.1151915.

MONTENEGRO, S.; RAGAB, R. Impact of possible climate and land use changes in the semiarid regions: a case study from North Eastern Brazil. Journal of Hydrology (Amsterdam), v. 434-435, p. 55-68, 2012. http://dx.doi.org/10.1016/j.jhydrol.2012.02.036.

MOSS, R.; BABIKER, M.; BRINKMAN, S.; CALVO, E.; CARTER, T. R.; EDMONDS, J.; ELGIZOULI, I.; EMORI, S.; ERDA, L.; HIBBARD, K.; JONES, R.; KAINUMA, M.; KELLEHER, J.; LAMARQUE, J.-F.; MANNING, M. R.; MATTHEWS, B.; MEEHL, J.; MEYER, L.; MITCHELL, J. F. B.; NAKICENOVIC, N.; O’NEILL, B.; PICHS, R.; RIAHI, K.; ROSE, S. K.; RUNCI,
P.; STOUFFER, R. J.; VAN VUUREN, D. P.; WEYANT, J. P.; WILBANKS, T. J.; VAN YPERSELE, J. P.; ZUREK, M. Towards new scenarios for analysis of emissions, climate change, impacts, and response strategies: IPCC Expert Meeting Report. Noordwijkerhout: Intergovernmental Panel on Climate Change, 2008. 155 p.

OLMSTEAD, S. M. Climate change adaptation and water resource management: a review of the literature. Energy Economics, v. 46, p. 500-509, 2014. http://dx.doi.org/10.1016/j.eneco.2013.09.005.

PBMC - Painel Brasileiro de Mudanças Climáticas. Impactos, vulnerabilidades e adaptação às mudanças climáticas. Rio de Janeiro: Universidade Federal do Rio de Janeiro, 2014. 414 p. Contribuição do Grupo de Trabalho 2 do Painel Brasileiro de Mudanças Climáticas ao Primeiro Relatório da Avaliação Nacional sobre Mudanças Climáticas.

PCMDI - Program for Climate Model Diagnosis and Intercomparison. CMIP5: Coupled Model Intercomparison project. 2016. Available from: $<$ http://cmip-pcmdi.llnl.gov/cmip5/availability.html>. Access in: 01 Jan. 2016.

PIELKE Sr, R. A.; WILBY, R. L. Regional climate downscaling: what's the point? Eos, Transactions, American Geophysical Union, v. 93, n. 5, p. 52-53, 2012. http://dx.doi.org/10.1029/2012EO050008.

PINHEIRO, P. L.; FREITAS, H. B.; CHAVES, F. A.; MAIA, E. C. M. Operação do Açude Castanhão para perenização do Rio Jaguaribe, ano 2003, Ceará, Brasil. In: SIMPÓSIO BRASILEIRO DE RECURSOS HÍDRICOS, 27., 2007, São Paulo. Porto Alegre: ABRH, 2007.

PORTO, R. L. L.; MÉLLO JUNIOR, A. V.; ROBERTO, A. N. AcquaNet: arquitetura, estratégias e ferramentas. In: SIMPÓSIO BRASILEIRO DE RECURSOS HÍDRICOS, 16., 2005, João Pessoa. Porto Alegre: ABRH, 2005.

SCHEWE, J.; HEINKE, J.; GERTEN, D.; HADDELAND, I.; ARNELL, N. W.; CLARK, D. B.; DANKERS, R.; EISNER, S.; FEKETE, B.; COLÓN-GONZÁLEZ, F. J.; GOSLING, S. N.; KIM, H.; LIU, X.; MASAKI, Y.; PORTMANN, F. T.; SATOH, Y.; STACKE, T.; TANG, Q.; WADA, Y.; WISSER, D.; ALBRECHT, T.; FRIELER, K.; PIONTEK, F.; WARSZAWSKI, L.; KABAT, P. Multi-model assessment of water scarcity under climate change. Proceedings of the National Academy of Sciences of the United States of America, v. 111, n. 9, p. 3245-3250, 2013. http://dx.doi.org/10.1073/ pnas.1222460110. PMid:24344289.

SHUKLA, J.; HAGEDORN, R.; MILLER, M.; PALMER, T. N.; HOSKINS, B.; KINTER, J.; MAROTZKE, J.; SLINGO, J. Strategies: revolution in climate prediction is both necessary and possible: a declaration at the world modelling summit for climate prediction. Bulletin of the American Meteorological Society, v. 90, n. 2, p. 175-178, 2009. http://dx.doi.org/10.1175/2008BAMS2759.1.

SIGEL, K.; KLAUER, B.; PAHL-WOSTL, C. Conceptualising uncertainty in environmental decision-making: the example of the 
EU Water Framework Directive. Ecological Economics, v. 69, n. 3, p. 502-510, 2010. http://dx.doi.org/10.1016/j.ecolecon.2009.11.012.

SILLMANN, J.; KHARIN, V. V.; ZHANG, X.; ZWIERS, F. W.; BRONAUGH, D. Climate extremes indices in the CMIP5 multimodel ensemble: part 1: model evaluation in the present climate. Journal of Geophysical Research, v. 118, p. 1-18, 2013.

SILVA, U. P. A.; OLIVEIRA, J. L. F.; BEZERRA, H. E. R. A experiência de gerenciamento participativo na Bacia Hidrográfica do Jaguaribe - Ceará. In: SIMPÓSIO DE RECURSOS HÍDRICOS DO NORDESTE, 3., 1996, Salvador. Porto Alegre: ABRH, 1996.

SILVEIRA, C. S. Modelagem integrada de meteorologia e recursos hidricos em múltiplas escalas temporais e espaciais: aplicação no Ceará e no setor bidroelétrico brasileiro. 2014. 352 f. Tese (Doutorado). Programa de Pós-graduação em Engenharia Civil, Departamento de Engenharia Hidráulica e Ambiental, Universidade Federal do Ceará, Fortaleza, 2014.

SILVEIRA, C. S.; SOUZA FILHO, F. A.; ARAUJO JUNIOR, L. M.; DIAS, T. A.; CABRAL, S. L. Análise das projeções de vazão média anual no sistema Jaguaribe-Metropolitano para os cenários RCP4.5 e RCP8.5 do IPCC-AR5 para o século XXI. In: SIMPÓSIO DE RECURSOS HÍDRICOS DO NORDESTE, 12., 2014, Natal. Natal: Água e Desenvolvimento, 2014.

SRH - Secretaria dos Recursos Hídricos do Estado do Ceará. Inventário Ambiental do açude Castanhão. Fortaleza, 2011a. 142 p.

SRH - Secretaria dos Recursos Hídricos do Estado do Ceará. Inventário Ambiental do açde Orós. Fortaleza, 2011b. 126 p.

SRH - Secretaria dos Recursos Hídricos do Estado do Ceará. Inventário Ambiental do açude Banabuiú. Fortaleza, 2011c. 111 p.

TAYLOR, K. E.; STOUFFER, R. J.; MEEHL, G. A. An overview of CMIP5 and the experiment design. Bulletin of the American Meteorological Society, v. 93, n. 4, p. 485-498, 2012. http://dx.doi. org/10.1175/BAMS-D-11-00094.1.

TEBALDI, C.; SMITH, R. L.; NYCHKA, D.; MEARNS, L. O. Quantifying uncertainty in projections of regional climate change: a bayesian approach to the analysis of multimodel ensembles. Journal of Climate, v. 18, n. 10, p. 1524-1540, 2005. http://dx.doi. org/10.1175/JCLI3363.1.

TORRES, R. R.; MARENGO, J. A. Uncertainty assessments of climate change projections over South America. Theoretical and Applied Climatology, v. 112, n. 1-2, p. 253-272, 2013. http:/ /dx.doi. org/10.1007/s00704-012-0718-7.

TORRES, R. R.; MARENGO, J. A. Climate change hotspots over South America: from CMIP3 to CMIP5 multi-model datasets.
Theoretical and Applied Climatology, v. 117, n. 3-4, p. 579-587, 2014. http://dx.doi.org/10.1007/s00704-013-1030-x.

VAN VLIET, M. T. H.; FRANSSEN, W. H. P.; YEARSLEY, J. R.; LUDWIG, F.; HADDELAND, I.; LETTENMAIER, D. P.; KABAT, P. Global river discharge and water temperature under climate change. Global Environmental Change, v. 23, n. 2, p. 450-464, 2013. http://dx.doi.org/10.1016/j.gloenvcha.2012.11.002.

VAN VUUREN, D. P.; EDMONDS, J.; KAINUMA, M.; RIAHI, K.; THOMSON, A.; HIBBARD, K.; HURT'T, C.; KRAM, T.; KREY, V.; LAMARQUE, J.; MASUI, T.; MEINSHAUSEN, M.; NAKICENOVIC, N.; SMITH, S. J.; ROSE, S. K. The representative concentration pathways: an overview. Climatic Change, v. 109, n. 1-2, p. 5-31, 2011. http://dx.doi.org/10.1007/s10584-011-0148-z.

WAGENER, T.; SIVAPALAN, M.; TROCH, P. A.; MCGLYNN, B. L.; HARMAN, C. J.; GUPTA, H. V.; KUMAR, P.; RAO, P. S. C.; BASU, N. B.; WILSON, J. S. The future of hydrology: an evolving science for a changing world. Water Resources Research, v. 46, n. 5, p. 1-10, 2010. http://dx.doi.org/10.1029/2009WR008906.

WATTS, R. J.; RICHTER, B. D.; OPPERMAN, J. J.; BOWMER, K. H. Dam reoperation in an era of climate change. Marine \& Freshwater Research, v. 62, n. 3, p. 321-327, 2011. http://dx.doi. org/10.1071/MF10047.

WILBY, R. L.; DESSAI, S. Robust adaptation to climate change. Weather, v. 65, n. 7, p. 180-185, 2010. http://dx.doi.org/10.1002/ wea. 543.

WILBY, R. L.; WIGLEY, T. M. L. Downscaling general circulation model output: a review of methods and limitations. Progress in Physical Geography, v. 21, n. 4, p. 530-548, 1997. http://dx.doi.org /10.1177/030913339702100403.

\section{Authors contributions}

Renato de Oliveira Fernandes: Literature review, text structure, simulations of reservoir yields and drafting the text.

Cleiton da Silva Silveira: Downscaling of the GCM precipitation data, correction of the bias of precipitation and simulation of the inflows to the reservoirs and text revision

Ticiana Marinho de Carvalho Studart: Advising and planning in all parts of the development of the study and text revision

Francisco de Assis de Souza Filho: Definition of the methodology, advising and planning in all parts of the study development 